\title{
FILSAFAT DINAMIS-INTEGRALISTIK; EPISTEMOLOGI DALAM PEMIKIRAN MUHAMMAD IQBAL
}

\author{
Ach. Maimun \\ Institut Ilmu Keislaman Annuqayah Guluk-guluk Sumenep \\ Email: mymoon221@gmail.com.
}

\begin{abstract}
Abstrak:
Kajian ini fokus menekankan pada aspek dinamis dan integralitas karakteristik pemikiran Iqbal. Spirit dinamisme dan integralitas merupakan ruh pemikiran Iqbal yang kurang mendapat perhatian dalam berbagai kajian. Dengan ruh ini Iqbal meramu pemikirannya untuk membangun peradaban Islam yang tenggelam dalam kejumudan. Untuk tujuan itu, Iqbal melakukan integrasi pada aspek fundamental, yaitu sumber pengetahuan berupa: afak, anfus dan sejarah. Dalam anfus terdapat tiga potensi, yaitu indera, akal dan intuisi. Semua perangkat ini merupakan kesatuan menuju penyempurnaan terus menerus pengetahuan hingga sampai pada puncaknya. Untuk terus bisa bergerak dinamis, kekuatan 'isyq dalam khudi berperan penting sehingga semua sumber dimaksimalkan secara simultan untuk menjelajahi objek pengetahuan yang merupakan kesatuan karena berasal dari Wujud Mutlak yang satu. Dengan ini Iqbal memperlihatkan upaya integrasi objek (fisik dan metafisik) yang dilanjutkan dengan integrasi tasawuf, filsafat dan sains. Iqbal juga mengintegrasikan pemikiran klasik dan modern serta pemikiran Islam dan Barat dengan tetap bersikap kritis. Pengetahuan yang diperoleh merupakan pedoman tindakan dalam bentuk 'amal sebagai wujud integrasi pengetahuan dan tindakan.
\end{abstract}

Kata Kunci: sumber pengetahuan, 'isyq, intuisi, integrasi.

\begin{abstract}
:
This study focuses on the dynamic and integral aspects of Iqbal. The spirit of dynamism and integrality is a discussion of Iqbal which has received less attention in various studies. With this spirit, Iqbal concocted successfully to build an Islamic civilization that was built in chaos. For that purpose, Iqbal integrates the fundamental aspects, namely the source of knowledge consists of afak, anfus and history. There are three potentials, namely the senses, reason and intuition. All these devices are a unity towards continuous improvement until they reach their peak. To continue to move dynamically, the power of $y$ 'isyq in the gathering mind is important so that all sources are maximized simultaneously to explore the object of knowledge which is the connection between the One Absolute Being. With this Iqbal succeeded in encouraging object integration (physical and metaphysical) which began with the integration of Sufism, philosophy and science. Iqbal also integrates classical and modern and challenges Islam and the West while remaining critical thinking. Knowledge gained from actions in the form of 'charity as a form of knowledge and action.
\end{abstract}

Keywords: source of knowledge, 'isyq, intuition, integration. 


\section{Pendahuluan}

Sosok Mohammad Iqbal adalah sosok yang multifaset. Ia adalah Ia seorang filsuf dan penyair sekaligus seorang sufi, dan ahli hukum dan politik. Ia gabungan dari seorang pemikir dan praktisi yang terjun langsung dalam kehidupan politik. Di antaranya itu terlihat dari karier politiknya yang cemerlang hingga terpilih menjadi ketua Muslim League pada 1930 dan mencetuskan berdirinya Negara Islam Pakistan 15 Agustus 1947. Ide "dinamisme" yang selalu disuarakannya telah memberi pengaruh besar pada masyarakat muslim di anak Benua India, ${ }^{1}$ bahkan ke seluruh dunia Islam.

Kehadirannya begitu penting dalam rangkaian pembaruan di Anak Benua India dan di bagian dunia lainnya. Sejak munculnya Sayyid Ahmad Khan yang menggagas pentingnya pengetahuan dan Sayyid Amir Ali yang mengusung gagasan bahwa Islam tidak menentang kemajuan modern, Iqbal mengibarkan "bendera perang" melawan kejumudan, kondisi statis dan beku pada kehidupan umat Islam. Bagi Iqbal inti hidup adalah gerak. Karena itu, jika umat Islam ingin hidup, ia harus dinamis, bergerak, maju menuju kehidupan yang lebih baik. Semangat ini yang mempermudah Mohammad Ali Jinnah untuk mengayam kekuatan dalam pembebasan dari kolonialisme Inggris dan pendirian negara Pakistan dengan nama Republik Islam Pakistan. ${ }^{2}$

Gagasan dinamisme yang selalu disuarakannya, bahkan dalam puisi-puisinya, jelas berakar dari pandangan dunia yang tak lepas dari perenungan filosofisnya. Keyakinan bahwa inti kehidupan adalah gerak merupakan kristalisasi dari pengembaraan intelektualnya, terutama dalam pergelutannya dengan filsafat di Barat dan di Timur. Selain itu, ia menekankan pada aksi, tidak hanya pemikiran abstrak sebagaimana kritiknya pada filsafat Yunani. Karena, menurutnya, pemikiran itu penting jika menjadi landasan aksi dan diwujudkan dalam kehidupan nyata di dunia. Di sini tampak Iqbal adalah seorang realistik. Dengan pandangan dasar ini, ia juga mengkritik tasawuf yang jumud dan dianggap menyimpang dari inti ajaran Islam. Hal itu berdasar pada fenomena yang dinilai "musyrik" dalam tasawuf yang telah dilembagakan. Ia juga mengkritik keras tasawuf yang hanya berkutat dengan ritus-ritus dan penampilan ekstra sederhana, juga ketakpedulian pada dunia. ${ }^{3}$

Tapi ia juga mengkritik Mu'tazilah yang terlalu mengandalkan rasionalitas dalam melihat agama dengan mengesampingkan pengalaman keagamaan yang

\footnotetext{
1 Untuk riwayat lebih lanjut tentang biografi Iqbal, lihat antara lain, A. Hafidz Dasuki, dkk., Ensiklopedi Islam, (Jakarta: Ichtiar Baru van Hoeve, 1994) II: 235-237; Abdul Wahhab Azzam, Filsafat dan Puisi Iqbal, terj. Ahmad Rofi'i Usman, (Bandung: Pusataka, 1985); dan Hafeez Malik (ed.), Iqbal: Poet Philosopher of Pakistan, (New York: Columbia University Press, 1971).

${ }^{2}$ Harun Nasution, Pembaharuan dalam Islam, Sejarah Pemikiran dan Gerakan, (Jakarta: Bulan Bintang: 1975), 199-200.

${ }^{3}$ Muhammad Iqbal, Javid Nama, terj. Shaikh Mahmud Ahmad (The Pilgrimage of Eternity (Lahore: Institute of Islamic Culture, 1961), 122-123. Bahkan Iqbal menyebut keberagamaan yang hanya berkutat dengan ritus sebagai "agama para pendeta, agama tetumbuhan dan bebatuan," seperti ditegaskan dalam potongan sajaknya dalam Bal-i Jibril. Lihat kutipan sajaknya dalam K. G. Saiyidain, Percikan Filsafat Iqbal Mengenai Pendidikan, terj. M. I Sulaiman, Diponegoro, (Bandung, Pustaka, 1981), 173.
} 
berada di luar logika. ${ }^{4}$ Sementara Al-Ghazali menjadi sasaran kritik karena sama sekali meragukan kemampuan filsafat setelah menemukan jalan tasawuf. ${ }^{5}$ Selain kirtik itu, Iqbal juga melancarkan kritik atas Barat yang dinilai materialistik. Secara lebih spesifik, ia juga mengkritik beberapa aliran filsafat Barat yang memberikan pengaruh atas Islam, semisal iealisme, realisme, rasionalisme dan hegelianisme dan intuisionisme.

Dari berbagai kritiknya itu, Iqbal yang tampak sangat dekat dengan al-Qur'an memiliki pandangan sendiri yang sebenarnya khas filsafat Islam, termasuk dalam persoalan epistemologinya. Persoalan epistemologi menjadi penting karena ia menjadi sarana produksi pengetahuan yang menentukan pandangan seseorang. Filsafat Barat memiliki wajah tersendiri karena cara pandang khasnya terhadap objek pengetahuan, cara mengetahui dan standar validitasnya. Demikian juga pandangan khas Iqbal tentang realitas yang kemudian melahirkan pemikirannya yang cermerlang dan mendudukkannya sebagai salah seorang filosof Islam modern yang terbesar.

\section{Pembentukan Pemikiran Iqbal}

Sebuah gagasan berakar lahir dari proses intelektual yang komlpeks. Ia memiliki landasan-landasan, unsur-unsur yang membentuk serta proses pembentuk yang saling berkelindang dalam jalinan yang rumit. Memahami gagasan seseorang, seperti Iqbal, tidak cukup dikaji pemikirannya sebagai produk pemikirannya (al-fikr ka al-muhtawa) atau kompilasi hasil pemikiran (majmu' alafkar), tapi yang tak kalah pentinga adalah mengkaji pemikiran dalam bentuk instrumen (al-fikr ka 'adat) atau proses-proses untuk memproduksi pemikiran (liintaj al-afkar). ${ }^{6}$ Karena ia merupakan dasar suatu pemikiran dan dengan itu para pengkaji lebih bisa memahami produk-produk pemikiran seseorang berikut perbedaannya dengan pemikiran yang lain berikut urgesinya. Dengan ini pula bisa dipahami bahwa pemikiran seseorang tidak terbentuk begitu saja secara instan atau merupakan bawaan sejak lahir. Sebagai "akal bentukan" (al-'aql almukawwani), suatu pemikiran terkait dengan berbagai faktor kultural sehingga cara dan produk pemikiran tertentu berbeda dengan yang lain atau masing-masing memikili karakteristik sendiri-sendiri. ${ }^{7}$

Terkait dengan pemikiran Iqbal, pembentukannya tidak bisa dilepas dari kultur di mana ia menjalani kehidupan dan pengembaraan intelektualnya. Kontak dengan berbagai budaya dan pertemuan intelektual dengan para pemikir lain baik langsung atau tidak merupakan latar yang membentuk pemikirannya sehingga menjadi khas dan unik. Iqbal lahir dan dibesarkan dalam keluarga religius, walaupun bukan elit dan berpendidikan tinggi. Ayahnya adalah seorang pengusaha

\footnotetext{
${ }^{4}$ Muhammad Iqbal, The Reconstruction of Religious Thoughts in Islam, (New Delhi: Kitab Bhavan, 1981), 4-5.

${ }^{5}$ Ibid, 4. Al-Ghazali dinilai tidak acuh terhadap potensi indera dan akal untuk memperoleh ilmu pengetahuan yang hakiki. Kesalahan Al-Ghazali adalah memisahkan antara intuisi dan akal, padahal-menurut Iqbal-keduanya tidak bisa dipisahkan. Lihat lebih lanjut halaman berikutnya.

${ }^{6}$ Muhammad 'Abid al-Jabiri, Takwin al-'Aql al-'Arabi (Beirut: Markaz Dirasat al-Wahdah al'Arabiyyah, 1984), 10.

${ }^{7}$ Ibid., 15.
} 
kecil di Kashmir, keluarga yang saleh dan cenderung mistik, selalu menyuruh Iqbal membaca Alquran. Pendidikan masa kecil ini memberikan warna dominan dalam pribadi Iqbal yang menjadikan Alquran sebagai basis pemikirannya, termasuk dalam gagasan epistemologisnya. Latar keluarga dan pendidikan dasar yang religius ini dikuatkan dalam pendidikan selanjutnya di Sialkot. Syamsul Ulama Maulana Mir Hasan, salah seorang gurunya, memberikan pengaruh besar dalam pembentukan jiwa, kepribadian dan gagasan keagamaan dini. ${ }^{8}$

Pengalaman pendidikan tinggi yang diperoleh di Lahore membuatnya lebih matang dalam pemikiran keagamaan dan ekspresinya dalam bentuk puisi sekaligus perluasan keilmuannya melalui pendalaman Bahasa Arab. Di Govermental College Lahore ini, Iqbal juga berkarier sebagai pengajar filsafat yang menjadi dasar pengembaraan keilmuannya ke Eropa. Saat menempuh pendidikan tinggi ini pula ia beruntung bertemu dengan Sir Thomas Arnold, seorang orientalis terkemuka Inggris yang mengapresiasi kemampuan Iqbal dan mendorongnya untuk melakukan pengembaraan intelektual ke Barat. Inspirasi ini diwujudkan Iqbal dengan belajar ke Cambridge di Trinity College di bawah bimbingan Mac Tagart dan James Ward. ${ }^{9}$ Di sini ia mendalami filsasfat dan hukum, berkenalan dengan pemikir Barat secara langsung atau melalui buku-bukunya. Sejak di sini pula Iqbal menjelajahi kebudayaan Barat dengan lahap sehingga menjadikannya paham secara mendalam sekaligus bisa memilah apa yang patut diambil dan ditolak, apa yang harus diterima dan dikritik. Jika Mir Hasan memberikan dasardasar keagamaan dan budaya Timur, maka Arnold membuka wawasan tentang Barat dan filsafatnya. ${ }^{10}$ Inilah dasar pemikiran integralistik Iqbal yang terus diperluas dan dimatangkan dalam proses belajar selanjutnya.

Di Jerman, ia memperoleh kesan mendalam dari dunia Barat yang membuatnya mendapat banyak inspirasi, dari Goethe, Nietzsche dan Hegel. Dengan menulis The Development of Metaphisics in Persia mendalami metafisika Timur dan memperkenalkannya ke Barat. Dari kajian ini Barat ba, nyak mengenal secara lebih mendalam filsafat dan spiritualitas Timur melalui tokoh-tokohnya sejak Zarathustra. Para orientalis diperkenalkan dengan para pemikir seperti Suhrawardi al-Maqtul, Abdul Karim al-Jili, Mulla Sadra hingga Mulla Hadi Sabzawari, yang sebelumnya hampir tak dikenal di Barat. ${ }^{11}$ Dengan kajian ini, Iqbal dikenal menguasi Barat dan Timur secara mendalam dan merumuskan sintesis yang membuatnya diakui sebagai pemikir besar baik di Barat atau di Timur.

Sekembalinya dari Barat dengan berbekal pegetahuan tentang filsafat dan kebudayaan Barat yang luas, ia berkarier sebagai guru besar filsafat dan sastra sekaligus politisi, Iqbal terus mematangkan pemikiran keagamaannya hingga menemukan pendekatan baru berikut spirit asli Islam yang dinamis, terutama

\footnotetext{
${ }^{8}$ Annemarie Schimmel, Sayap Jibril: Gagasan Religius Muhammad Iqbal, terj. Shohifullah, (Yogyakarta: Lazuardi, 2003), 38-39. Ali Audah, "Muhammad Iqbal: Sebuah Pengantar" dalam Muhammad Iqbal, Membangun Kembali Pikiran Agama Dalam Islam, terj. Ali Audah (Jakarta: Tintamas, 1982), 111.

${ }^{9}$ Ibid., 41.

${ }^{10}$ Miss Luce-Claude Maitre, Pengantar ke Pemikiran Iqbal, terj. Djohan Effendi (Bandung: Mizan, 1989), 14.

11 Ibid., 42.
} 
berkat perkenalannya dengean filsafat vitalis di Barat. Dengan ini Iqbal terus menyuarakan filsafat dinamisnya terkait dengan kehidupan keagamaan dalam puisi dan kuliah-kuliahnya. Asrar-i Khudi (Rahasia Diri), Rumuz-i bekhudi (Misteri Ketidaan Diri) dan Payam-i Masyriq (Pesan dari Timur) adalah di antara karya puisinya yang membawa spirit dinamisme. ${ }^{12}$

Gagasannya terus dimatangkan dengan kesempatan berbagai lawatan ke berbagai dunia Islam seperti Turki, Mesir dan Persia. Ia juga berkesempatan melakukan korespondensi dengan Mustafa al-Maraghi dari Universitas Al-Azhar dan Khalid Khalil dari Universitas Istambul. Semangat pembaruan yang berbasis filsafat ini dituangkan dalam berbagai kuliahnya di Univesitas Hyderabad, Madras dan Aligarh yang dibukukan dengan judul The Reconstruction of Religious Thought in Islam. Buku yang selanjutnya diterjemahkan ke dalam Bahasa Perancis ini menarik banyak pemikir Eropa sehingga Iqbal di kenal luas dengan gagasannya yang orisinal. Ini membuat Iqbal diundang untuk memberikan kuliah ke banyak universitas terkemuka Eropa dalam berbagai lawatannya seperti ke Madrid University dan Oxford University. Dalam berbagai lawatannya itu pula Iqbal sempat berdiskusi dengan banyak pemikir seperti Henry Bergson, Luois Massignon, Asin Palacios, bahkan Mussolini. ${ }^{13}$ Dengan semua bahan itu, Iqbal melakukan sintesis antara Barat dan Timur, antara agama dan filsafat, antara spiritualitas dengan rasionalitas. Bagunan gagasan ini berbasis Alquran dan dijiwai oleh semangat dinamis. Ia kritis kepada Islam yang tertinggal dan jumud, kritis terhadap tasawuf yang mengabaikan dunia, tapi juga kritis kepada Barat dan materialistik. Semua gagasan itu dibangun di atas filsafat pengetahuan yang utuh.

\section{Sumber Pengetahuan}

Sekalipun dikenal sebagai filsuf, Iqbal sangat dekat dengan al-Qur'an. Iqbal begitu terkesima dengan al-Qur'an. Ia melihat bahwa al-Qur'an memiliki daya penyadaran pada keinsyafan batin manusia dalam hubungannya dengan Allah, sesama manusia dan alam. Al-Qur'an adalah dasar utama ajaran Islam untuk kehidupan secara menyeluruh, sementara Islam sebagai agama tidak bisa disejajarkan dengan objek kajian bebas filsafat lainnya. ${ }^{14}$ Karena itu tidak berlebihan jika Asif Iqbal Khan berkesimpulan bahwa basis filsafat Iqbal adalah agama. ${ }^{15}$

Kedekatan Iqbal dengan al-Qur'an juga terlihat dalam pemikirannya tentang filsafat ilmu pengetahuan (epistemologi). Menurut Iqbal, ilmu pengetahuan bersumber dari tiga hal: (1) afaq (dunia), (2) anfus (diri/ego), ${ }^{16}$ dan (3) sejarah. Pemilahan sumber pengetahuan ini berbeda dengan pemikiran para pemikir lainnya yang biasanya membangi sumber ilmu dengan indera, akal dan

\footnotetext{
12 Ibid., 46 dst.

13 Ibid., 57.

${ }^{14}$ Mohammad Iqbal, The Reconstruction of Religious, 2, 7.

${ }^{15}$ Iqbal Khan, Some Aspects of Iqbal's Thoughts, (Lahore: Islamic Book Service, 1977), 3 dan 8.

${ }^{16}$ Istilah teknis ini memang diambil dari bahasa al-Qur'an sendiri. Istlah afaq dan anfus diambil dari Q. S. 41: 53. Sedang tentang sejarah diambil dari pesan-pesan ayat tentang sejarah, antara lain (Q.S. 14: 5).
} 
hati. ${ }^{17}$ Syed Muhammad Naquib al-Attas menambahkan khabar shadiq. ${ }^{18}$ sementara klasifikasi lainnya ilmu pengetahuan berdasar sumbernya menjadi al'ilm al-'aqli (rasional) al-'ilm al-naqli (berdasar wahyu) sesuai dengan sumbernya yakni potensi rasional manusia dan wahyu. ${ }^{19}$

Pertama, afaq. Yang dimaksud afaq sebagai sumber ilmu adalah realitas fisik atau dunia lahiriah. Dalam hal ini Iqbal tidak membedakan istilah "dunia" (world) dengan "alam semesta" (nature). Ia hanya perlu dibedakan dari anfus sebagai sesuatu yang berada pada diri manusia. anfus berhadapan dengan afaq sebagai realitas luar. Dengan demikian, afaq mencakup segala alam raya dengan segenap isinya, mulai dari bumi, bulan, matahari dan seterusnya.

Alam menjadi sangat penting untuk dipelajari, karena ia mengandung kebenaran. Realitas fisik bukan sekedar realitas semu yang hanya memberikan kebenaran semu seperti banyak diragukan sementara filsuf. Pandangan tentang arti penting alam juga menegaskan sikapnya terhadap kaum sufi yang memandang rendah alam. Justru aspek kebenaran yang disediakan alam jika direnungkan secara serius akan mengantar pada kebenaran puncak yang hakiki (Ultimate Reality) atau Tuhan, yang menjadi pusat perhatian sekaligus tujuan akhir kaum sufi. ${ }^{20}$ Karena itu, dunia jelas bukan sekadar main-main, tidak penting dan "penjara" bagi orang mukmin (sijn al-mu'min) seperti sering dikutip kaum muslim lainnya.

Dengan pandangannya ini ia dapat dinilai sebagai seorang filsuf realis, bukan idealis. Islam berkata "ya" pada dunia materi dan menunjukkan jalan untuk menguasainya dengan tujuan menemukan dasar bagi hukum hidup yang nyata, katanya. ${ }^{21}$ Iqbal mendasakan pendapatnya pada ayat-ayat al-Qur'an, antara lain: Q.S. Al-Baqarah/2: 164, Al-An'am/6: 97-99, Al-Furqan/25: 45-46, AlGhasyiyah/88: 17-20, dan Al-Rum/30: 22.

Kedua, anfus. Yang dimaksud dengan sumber ilmu ini adalah manusia sebagai kesatuan jiwa-raga, ${ }^{22}$ yakni manusia sebagai individualitas yang berkesadaran, dan yang berkata "aku" ( $I$ am $).{ }^{23}$ Manusia sendiri merupakan sumber ilmu atau informasi bagi manusia lainnya. Manusia memiliki kemampuan untuk menangkap seluruh realitas, materi dan non materi. Karena dalam diri manusia terdapat dimensi lahir dan dimensi batin yang mengandung tiga potensi epistemologis, yaitu: (1) indera, untuk objek fisik-material atau dunia eksternal,

\footnotetext{
${ }^{17}$ Mehdi Golshani, The Holy Qur'an and the Sciences of Nature, (New York: Global Publications, 1998), 178 dan 216. Syamsuddin Arif, "Prinsip-Prinsip Dasar Epistemologi Islam," dalam Adian Husaini et. Al., Filsafat Ilmu Perspektif Barat dan Islam, (Jakarta: Gema Insani Press, 2013), 114.

${ }^{18}$ Muhammad Naquib al-Attas, Islam dan Filsasfat Ilmu Pengetahuan, terj. Saiful Muzani (Bandung: Mizan, 1995), 34-40.

${ }^{19}$ Mulla Shadra membaginya menjadi al-'ilm al-'shuwari (konsepsional) yang berdasar kemampuan manusia, dan al-'ilm al-ladunni (presensial) yang berdasar wahyu, baik berupa al-Qur'an atau ilham kepada orang-orang suci. M. M. Sharif, A History of Muslim Philosophy, (Wiesbaden: Ottoharrassowits, 1966), 936.

${ }^{20}$ Mohammad Iqbal, The Reconstruction of Religious, 13.

21 Ibid., 10.

22 Ibid, 95. Bandingkan dengan Shahid Hussein, "Iqbal's Concept of Personal Identity," dalam Mohammed Ma'ruf (ed.), Contributions to Iqbal's Thought, (Lahore: Islamic Book Service, 1977), 43. ${ }^{23}$ Ibid, 46.
} 
(2) akal, untuk objek non fisik yang masih terkait dengan fisik, dan (3) intuisi, untuk objek non fisik yang lebih tinggi, yang sama sekali terlepas dari dunia fisik. Pembagian ini rupanya sejalan dengan rumusan Alquran yang terdiri dari nadzar, fikr dan 'aql, dan qalb. ${ }^{24}$ Menariknya, Iqbal tidak menyebut Alquran sebagai sumber pengetahuan.

Pertama, indera. Kemampuan indera atas pencapaiannya pada objek fisik melahirkan dukungannya pada Ibnu Taimiyah yang menolak logika formal Aristoteles. Bagi Iqbal, pengetahuan empirik dari proses induksi merupakan argumen yang lebih bisa dipercaya. ${ }^{25}$ Tentu hal ini terkait dengan dunia fisikmaterial. Bahkan al-Qur'an lebih banyak berbicara tentang hal-hal kongkrit dan empirik. Sementara untuk hal yang tidak empirik, al-Qur'an menyatakan sebagai urusan Allah. Misalnya tentang roh (Q.S. Al-Israa': 85). ${ }^{26}$

Yang perlu dicatat, bahwa empirisme Iqbal berbeda dengan Barat. Karena Iqbal tidak serta merta menolak realitas non-empirik. Empirisme hanya salah satu bagian dari sistem epistemologinya, bukan empirisme radikal, yang biasanya merujuk pada David Hume [1711-1776]). Hume menganggap pengalaman empirik merupakan kriteria tertinggi dalam sistem epistemologinya. Bagi Hume pengetahuan harus didasarkan kepada pengalaman atas peristiwa, bukan atas penalaran apriori, sehingga segala bentuk penalaran tidak bisa diterima sebagai kebenaran tanpa merujuk kepadan pengalaman atas peristiwa empirik. ${ }^{27}$

Kedua, akal atau potensi pikir. Tidak terdapat definisi akal yang seragama di kalangan para filosof, termasuk oleh Iqbal sendiri. Ia hanya berbicara tentang potensi, kedudukan dan kemampannya. Bagi Iqbal, agama tidak ada artinya jika akal dikungkung sehingga tidak bisa berpikir secara kritis dalam memahami dan melaksanakannya. ${ }^{28}$ Akal bisa bergerak dari wilayah fisik ke wilayah non fisik dengan sangat cepat. Kemampuan konseptualnya bisa mengubah benda-benda alami menjadi benda-benda budaya. ${ }^{29}$ Dengan akal pula, manusia bisa berperan lebih jauh dalam menjalankan tugasnya sebagai khalifah. "Tuhan menciptakan pohon, lalu kita ciptakan kursi," katanya.

Walaupun sangat menjunjung tinggi akal, ternyata Iqbal bukan penganut rasionalisme radikal yang menganggap kemampuan akal tak terbatas atau akal sebagai satu-satunya alam mencapai kebenaran hakiki. Akal bukan satu-satunya tumpuan epistemologi. Karena akal memiliki banyak kelemahan. Misalnya, ia bisa

\footnotetext{
${ }^{24}$ Agus Salim Lubis, "Epistemologi Ilmu Pengetahuan dan Relevansinya dalam Studi Al-Qur'an," Jurnal Hermeunetik, Vol. 8, No. 1, Juni 2014, 54.

25 Ibid., 129.

${ }^{26}$ Ibid., 14.

${ }^{27}$ A. Sonny Keraf dan Mikhael dua, Ilmu Pengetahuan: Sebuah Tinjauan Filosofis (Yogyakarta: Kanisius, 2010), 54

28 "Religion stands in greather need a rasional foundation of its Ultimate principles," katanya. Lihat, Mohammad Iqbal, The Reconstruction of Religious, 2.

29 "In its deeper movement, however, thought is capable of movement the various finite concepts are merely moments. In its essential nature, then, thought is not static; it is dyamic and unfolds its internal infinitude in time like the seed which, from the very beginning, caries within itself the organic uity of the tree as present fact." Ibid, 6. Lihat juga halaman. 13. Bandingkan dengan Mohammad Iqbal, Stay Reflection, ed. Javid Iqbal, SH. (Lahore: Ghulam Ali \&Son, 1961), 66.
} 
meragukan dirinya sendiri. ${ }^{30}$ Tampak Iqbal berusaha proporsional dalam penggunaan akal serta kritis atasnya sebagai potensi besar tapi juga memiliki kelemahan. Rasionalisme justru melihat akal adalah satu-satunya penentu kebenaran, hanya dengan menggunakan prosedur tertentu dari akal saja kita bisa sampai pada pengetahuan yang tak mungkin salah, sedang dari lainnya harus diragukan, seperti dikampanyekan Descartes. ${ }^{31}$

Ketiga, intuisi yang juga disebut qalb atau fu'ad. Intuisi merupakan sejenis pandangan batin (inner insight) yang dapat menghubungkan kita dengan aspekaspek Realitas lain selain dari realitas yang bisa dijangkau dengan indera. ${ }^{32}$ Tapi dalam kesempatan lain, Iqbal mengikuti Bergson (159-1941) dengan memberi pengertian intuisi dengan "sejenis intelek yang lebih tinggi" (a higher kind of intellect). ${ }^{33}$ Tidak ditemukan rincian lebih jauh tentang terma ini. Ia lebih banyak berbicara tentang fungsinya untuk memberikan pengetahuan tentang hal-hal yang tidak bisa dijangkau oleh indera atau akal.

Dengan intuisi, Iqbal menunjukkan bahwa hal-hal yang ghaib juga memiliki realitas. Tapi untuk mengetahuinya tidak bisa menggunakan indera atau akal. Kedua perangkat itu memiliki wilayah sendiri dan tidak bisa menjangkau ke wilayah lain yang sering juga disebut metafisika. Dengan intuisi, Iqbal bisa berbicara banyak tentang pengalaman tasawuf yang integral dengan realitas yang lain, yaitu dunia fisik.

Ketiga, sejarah. Bagi Iqbal, sejarah adalah rekaman kehidupan masa silam. ${ }^{34}$ Tapi Iqbal tidak banyak berbicara tentang sejarah. Hanya ketika ia berbicara tentang hal-hal yang terkait dengan sejarah, ia tidak hanya berbicara tentang datadata deskriptif yang mati, tapi juga menganalisis secara tajam dan kritis. ${ }^{35}$ Dalam menjadikan sejarah sebagai sumber pengetahuan, Iqbal mengingatkan agar hatihati dengan sumber dan interpretasinya. Tampak bahwa sejarah memang bukan semata informasi, tapi juga melibatkan interpretasi. Sikap kritis atas sumber sejarah tersebut didasarkan pada ayat al-Qur'an (Q.S. Al-Hujurat/49: 6). ${ }^{36}$ Iqbal melihat sejarah begitu penting bagi sumber kehidupan. Karena dengan berbekal pengetahuan sejarah, seseorang dapat tergugah kesadarannya, bisa bertindak lebih cermat dan menyadai tujuan hidup. Ia akan sangat bermanfaat bagi

\footnotetext{
30 "Pikiranku ragu/tentang ada dan tiadaku/". Lihat selengkapnya sajak ini dalam Muhammad Iqbal, Payam-i, 107. Pada halaman lain dalam buku ini Iqbal menyatakan: "Tipu daya intelek/adalah kehormatan," 116. Dalam Javid Nama, Iqbal menyatakan: "Dalam sorotan pengamatan intelek/alam semesta hanya tampil sebagai ilusi dan fatamorgana." Lihat Javid Nama, 2. Lebih keras lagi ia menyatakan: "Apa yang akan kubuat? Intelek yang licik/telah mengikatkan pad kancingnya/sekali kejap aku berdoa. Gerak mata-Mu/mungkin akan mematahkan jampi-jampinya. Lihat Payam-i, 126.

31 A. Sonny Keraf dan Mikhael dua, Ilmu Pengetahuan, 45-46.

32 Mohammad Iqbal, The Reconstruction of Religious, 15-16.

33 Ibid., 3.

${ }^{34}$ Atau "gramafon besar tempat menyimpan suara bangsa-bangsa di masa silam", menurut istilah Iqbal sendiri. Lihat Mohammad Iqbal, Stray Reflection, 107.

${ }^{35} \mathrm{Abu}$ al-Hasan Ali al-Husni al-Nadwi, Percikan Kegeniusan Dr. Muhammad Iqbal, terj. Suyibno, Hz. M. (Jakarta: Integrita Press, 1985), 211.

36 Syarif Hidayatullah, "Epistemologi Pemikiran Muhammad Iqbal," Jurnal Filsafat, Vol. 24, Nomor 1, Februari 2014, 122.
} 
kepentingan masa depan. "Jika engkau ingin meraih kehidupan yang abadi, jangan putuskan pautan dulu, kini dan kelak," katanya dalam potongan sajaknya. ${ }^{37}$

\section{Metode dan Validitasnya}

Kecuali menjelaskan objek masing-masing sumber yang lebih merupakan alat memperoleh pengetahuan, Iqbal tidak merinci secara verbal tentang cara memperolehnya. Indera digunakan untuk objek empirik, akal untuk objek logis dan intuisi untuk objek metafisik. Searah dengan kritiknya terhadap aliran-aliran yang menekankan pada salah satu aspek tersebut (empirisme, rasionalisme dan tasawuf), ${ }^{38}$ Iqbal menegaskan bahwa dalam pencapaian pengetahuan, masingmasing dari ketiga alat itu tidak bisa bekerja sendiri-sendiri. ${ }^{39}$ Inilah yang menegaskan bahwa epistemologi Iqbal adalah epistemologi yang integral, karena menggunakan segenap potensi dan sumber secara simultan dan saling menyempurnakan, bukan menggunakan secara parsial, dikotomis dan konfrontatif sebagaimana banyak terlihat dalam tradisi filsafat.

Indera dalam upaya memperoleh pengetahuan, perlu dukungan akal untuk mengolah informasi yang masuk hingga akhirnya menarik kesimpulan. Bahkan selain itu, dorongan untuk menjaring pengetahuan atas objek fisik juga mengharuskan adanya "ilham" yang bisa diterima oleh intuisi. Ilham dalam hal ini adalah informasi awal atas adanya pengetahuan pada suatu objek yang kemudian ditarik oleh indera dan diolah oleh akal. ${ }^{40}$ Akal juga tidak bekerja secara independen dari yang lain. Walaupun ia berhubungan dengan objek-objek logis, tapi kesimpulan rasional yang diperolehnya memerlukan keterkaitan dengan indera dan intuisi. Seorang yang memperoleh keyakinan dari penalaran logisnya memerlukan aktualisasi pada wilayah kongkrit. Keterkaitannya dengan intuisi dijelaskan bahwa keduanya berasal dari akar yang sama tapi memiliki kemampuan berbeda. Intuisi punya peran untuk menjangkau realitas tak terjangkau oleh akal dan indera. Walaupun demikian, ia memerlukan kontribusi akal dan indera sebaga bahan awal dan titik pijak untuk masuk ke realitas yang menjadi bidangnya.

Bagi Iqbal, ketiga alat yang merupakan potensi tersebut harus bergerak bersama sehingga bisa menghasilkan pengetahuan yang menyeluruh, tidak dipecah-pecah seperti yang ditunjukkan oleh aliran-aliran sejenis empirisme dan rasionalisme. Pengetahuan yang diperoleh indera dan akal masih parsial sehingga untuk mencapai pengetahuan yang utuh harus melibatkan intuisi. ${ }^{41}$ Pembedaan yang ditunjukkan Iqbal hanya sebagai pembedaan dominasi dalam aktivitas memperoleh pengetahuan, bukan pemisahan sama sekali. Hal itu terjadi sesuai dengan objek yang menjadi titik tolak upaya memperoleh pengetahuan. Pada objek fisik, aktivitas indera dominan, sementara yang lain menyusul dan

\footnotetext{
37 Seperti dikutip oleh Muhammad Munawar, Iqbal and Qur'anic Wisdom, (Lahore: Islamic Book Foundation, 1981), 66.

38 Danusiri, Epistemologi Dalam Tasawuf Iqbal, (Yogyakarta: Pustaka Pelajar, 1996), 26-34.

${ }^{39}$ Mohammad Iqbal, The Reconstruction of Religious, 2-3.

${ }^{40}$ M. Saeed Sheikh, "Iqbal's Main Religio-Philosophical Doctrines," dalam Saeed Sheikh (ed.), Studies in Iqbal's Thought and Art, (Lahore: Bazm-i Iqbal, 1972), 35.

41 Mohammad Iqbal, The Reconstruction of Religious, 2-3, 15.
} 
menyempurnakan kerja indera. Dalam persoalan logik-matematik, indera dan intuisi tidak banyak berperan. Tapi ketika menyangkut objek metafisik, maka intuisi berada di garda depan.

Dalam kelanjutannya, Iqbal menyebut pengetahuan yang diperoleh dari intuisi dengan 'isyq (cinta), sedang yang diperoleh dari indera dan akal tetap disebut 'ilm (ilmu biasa). Perbedaan penyebutan itu tampaknya didasarkan pada pengistimewaan atas ilmu yang diperoleh dari intuisi sebagai "intelek yang lebih tinggi". Pengistimewaan itu wajar karena Iqbal menilai bahwa 'isyq merupakan ilmu hakiki, yang dapat menjadi pembimbing ilmu biasa dan sebagai faktor penting dalam pengembangan diri dan kekuatan yang dahsyat. ${ }^{42}$ Orang yang telah mencapai tingkat pengetahuan ini akan memiliki kemampuan luar biasa sekaligus bisa mengarahkan perjalanan sejarah. Yesus dan Budha adalah di antara contohnya, yang ajaran-ajarannya tetap dianut dan mewarnai sejarah manusia.

Tapi apa standar validitasnya? Dalam hal ini Iqbal tidak memberikan penjelasan detail. Biasanya, jika tidak ada komentar kritis, pandangan yang ada diterima oleh Iqbal, atau ia memiliki pandangan yang sama dengan pandangan yang sudah ada. Pandangan yang telah ada menyatakan bahwa validitas pengetahuan empirik adalah korespondesi, sedang pengetahuan rasional dengan koherensi. Yang menjadi persoalan adalah pengetahuan yang diperoleh dari intuisi. Kebenarannya tidak bisa diukur menurut standar korespondensi atau koherensi, sementara Iqbal menegaskannya sebagai pengetahuan yang juga objektif, 43 bahkan merupakan pengetahuan tertinggi, karena ia dapat menjangkau realitas ultim, sebagai realitas hakiki atau Wujud Mutlak.

Dalam hal ini Iqbal sejalan dengan pemikiran para sufi, bahkan dengan Kant, bahwa realitas ultim, sebagai Wujud Mutlak, merupakan tujuan akhir pengembaraan spiritual tidak bisa dijangkau dengan rasio yang cara kerjanya dibatasi oleh pengalam dan ruang-waktu. Tapi ia juga mengkritik Kant yang menyatakan bahwa satu-satunya pengalaman adalah pengalaman inderawi. Karena ada pengalaman mistik sebagai pengalaman objektif di atas pengalaman inderawi yang: (1) bersifat langsung, (2) tak bisa dianalisis, (3) melebur dengan realitas ultim, (4) tidak dapat dikomunikasikan, (5) bersifat non-serial, tapi pure movemen atau duration. ${ }^{44}$ Dalam konteks ini, Iqbal memperlihatkan pengaruh Bergson dalam gagasannya, walaupun dalam tradisi Barat, pengetahuan intuitif teetap harus divalidasi dengan inderan dan rasio. ${ }^{45}$ Inilah yang menjadi titik beda dengan pengetahuan intuitif Iqbal yang diposisikan lebih tinggi dari pengetahuan

\footnotetext{
42 When the self is made strong by love/Its power rules the whole world/The heavenly sage who adorned the sky with stars/Plucked these buds from the bought of the self/Its becomes God's hand/The moon is split by its fingers/It's the arbitrator in all the quarrels of the world. Demikian kata Iqbal. Lihat Mohammad Iqbal, Asrar-i Khudi, terj. R. A. Nicholson, (Lahore: Mohammad Ashraf Kasmiri Bazar, 1950), 25.

43 Suhermanto Ja'far, “Epistemologi Tindakan Muhammad Iqbal," Jurnal Teosofi, Volume 5, Nomor 1, Juni 2015, 89.

${ }^{44}$ Muhammad Iqbal, The Reconstruction of Religious, 27-35.

45 Titus, Smith dan Nolan, Persoalan-Persoalan Filsafat, terj. H.M. Rasjidi (Jakarta: Bulan Bintang, 1984), 207-208.
} 
inderawi dan rasional sehingga kebenarannya tidak menunggu "vonis" indera dan rasio.

Tapi kebenaran tersebut berkaitan dengan objek metafisik yang di luar jangkauan indera. Maka validitasnya harus melalui "pengalaman langsung" (direct experience). Karena peliknya kebenaran spiritual, biasanya para sufi yang mencapai tingkat ini tidak bisa menggambarkannya secara rasional. Iqbal sepenuhnya menyadari itu sehingga ia berusaha memberikan penjelasan. Baginya, pengalaman mistik seperti pengalaman terhadap objek lain, walaupun totalitasnya memang tidak bisa dijelaskan, karena bersifat perasaan sebagai hubungan yang sangat intim. ${ }^{46}$

Misalnya, pengetahuan tentang penderitaan orang lain sebatas berdasarkan ekspresi lahir tanpa merasakannya, sementara pengalaman mistik yang melahirkan pengetahuan hakiki atas objek metafisik tersebut justru melibatkan diri dan turut merasakan dalam dirinya. Dengan begitu, ungkapan-ungkapan yang muncul sama sekali tidak mewakili dan lebih bersifat simbolik. ${ }^{47}$ Karena itu, untuk bisa menguji kebenarannya adalah melakukan langkah-langkah seperti yang dilakukan oleh para mistikus. Sebagaimana kita tidak bisa mengingkari realitas rasa sakit karena kita tidak bisa merasakannya, atau kita tidak bisa melihat secara empirik wujud rasa sakit atau memahaminya melalui logika.

Integralitas epistemologi Iqbal juga tampak di sini, dalam kaitan dengan objek: yaitu, realitas inderawi, realitas abstrak rasional, dan realitas metafisik hingga realitas ultim atau Wujud Mutlak yang diakui sebagai induk dari semua realitas. ${ }^{48}$ Ia tidak membatasi objek pengetahuan pada ranah inderawi dan abstrak rasional semata. Bahkan Iqbal menegaskan bahwa seluruh jenis objek dari yang empirik dan non empirik sejatinya adalah realitas yang saling terkait dan integral dengan Wujud Mutlak sebagai asalnya. Wujud Mutlak, merangkum ego-ego terbatas dalam wujudnya tanpa menghapus eksistensi mereka Karena itu segenap realitas tidak bisa dipahami dan diperlakukan secara parsial dan atomistik. Karena Wujud Mutlak sebagai asal yang mencakup segala realitas, Iqbal menegaskan, dengan demikian kodrat realitas yang sesungguhnya bersifat spiritual. ${ }^{49}$ Dengan demikian, integralitas itu juga mewujud dalam integrasi ilmu pengetahuan, antara tasawuf dengan ilmu kealaman dan kemanusiaan melalui integralitas ketiga objek di atas.

Keseluruhan gagasan epistemologis Iqbal di atas didasarkan pada konsep khudi (individualitas/jiwa) yang untuk mencapai pengetahuan memerlukan isyq (cinta) yang berkarakter dinamis. Ini ditegaskan karena memperlihatkan karakteristik menonjol Iqbal sebagai filosof-sufi yang memandang segenap realitas sebagai bersifat spiritual. Dengan ini Iqbal juga memperlihatkan integralitas gagasannya karena menyatukan metafisika Timur dan Barat. Dalam hal ini ia mendapat inspirasi dan elan vital Bergson di satu sisi dan kritik atas tasawuf yang

\footnotetext{
46 Mulyadhi Kartanegara, Menyingkap Tirai Kejahilan: Pengantar Epistemologi Islam, (Bandung: Mizan, 2003), 84-101.

47 Danusiri, Epistemologi dalam, 140-143.

48 Muhammad Iqbal, The Reconstruction of Religious, 54.

49 Ibid., 38-39.
} 
jumud di sisi lain. Bagi Iqbal, dalam khudi manusia terdapat kekuatan 'isyq yang mendorong manusia untuk mengetahui semua realitas, melakukan tindaktindakan bermakna bagi kehidupan yang disebut 'amal sehingga manusia menjadi insan kamil. Konsep yang dipinjam dari al-Jili ini merupakan orientasi semua gerak pengetahuan dan tindakan manusia untuk mengemban tugas khalifah dalam arati co-creator (mitra pencipta). ${ }^{50}$

Secara epistemologis ${ }^{51}$, dalam khudi terdapat intuisi yang mengandung 'isyq yang membuat manusia terus dinamis dalam mengembangkan pengetahuan. Bahkan dalam kesempatan lain, pengetahuan tentang realitas ultim diakui sebagai pengetahuan hakiki yang disebut 'isyq. Gagasan 'isyq ini merupakan salah satu gagasan orisinil Iqbal. ${ }^{52}$ Walaupun telah banyak sufi yang berbicara tentang "cinta spiritual" mulai dari Rabi'ah al-'Adawiyah (717-801 M) hingga Jalaluddin Rumi (1207-1273), tapi gagasan cinta Iqbal berbeda. Bagi Iqbal, 'isyq bukan sekedar pengalaman spiritual yang berupa maqam (station) atau hal (state) dalam tasawuf, tapi ia menjadi bagian dari epistemologi dalam pencapaian kebenaran hakiki. Orang yang telah memiliki 'isyq akan memperoleh kebenaran hakiki. Karena itu ia tidak dihantui oleh keraguan sedikitpun, bahkan akan memberikan kekuatan luar biasa pada diri yang bersangkutan. ${ }^{53}$

'Isyq sejatinya adalah asal kehidupan, karena Tuhan mencipta berdasar cinta atau rahmah. Ia menggerakkan Tuhan untuk mencipta. Cinta dalam diri manusia juga menggerakkannya menuju perubahan. Dalam ranah pengetahuan, 'isyq merupakan instrumen penggerak menuju perubahan pengetahuan menuju kesempurnaan hingga mencapai kebenaran hakiki (ma'rifat Allah). Karena itu, epistemologi Iqbal yang mendapat energi 'isyq memperlihatkan spirit dinamis, terus bergerak tanpa henti sehingga mencapai Wujud Mutlak yang merupakan kebenaran hakiki dan pusat realitas. Di sini Iqbal tidak menyebutkannya sebagai penyatuan (ittihad) atau kelenyapan (fana'), tapi ia menyebutnya sebagai ma'rifat, dengan tetap menganggap Wujud Mutlak adal objek dan manusia yang mengetahuinya adalah subjek, yang tidak benar-benar akan menyatu sebagaimana sering dipahamai dari paham sufi. ${ }^{54}$

Dengan proses seperti ini, Iqbal mengintegrasikan epistemologi dengan metafisika, dengan menolak tasawuf yang negatif dan mengubahnya dengan tasawuf positif yang dinamis, mengambil bagian-bagian dari filsafat Barat dengan modifikasi-modifikasi sehingga melahirkan rumusan gagasan yang unik. Bahkan, Iqbal menegaskan bahwa 'isyq itu sendiri bukan kekuatan mandiri, karena ia harus ditopang oleh rasionalitas, sebagaimana rahmah tidak bisa dilepaskan dari 'ilm.

\footnotetext{
50 Suhermanto Ja'far, “Epistemologi Tindakan,” 93-94.

51 Moh. Wardi, Problematika Pendidikan Islam Dan Solusi Alternatifnya (Perspektif Ontologis, Epistemologis dan Aksiologis), TadrîsVolume 8 Nomor 1 Juni 2013, 58.

52 Walaupun istilah 'isyq sebelumnya telah digunakan oleh Jalaluddin Rumi dalam gagasannya tentang cinta spiritual, sementara para sufi yang lain menggunakan istilah mahabbah atau hubb. Biasanya ia dinisbatkan kepdaa Rabi'ah al-'Adawiyah sebagai salah satu tokoh terpentingnya. Ach. Maimun, "Mahabbah dalam Tasawuf Rabi'ah al-'Adawiyah (Apresiasi atas Rintisan Mistik Sejati dalam Islam)," Jurnal Millah, Vol III, No. 2, Januari 2004.

53 Mohammad Iqbal, Stray Reflection, 67.

54 Suhermanto Ja'far, "Epistemologi Tindakan," 89-90.
} 
Dengan demikian, ia juga mengintegrasikan antara tasawuf dan sains. ${ }^{55}$ Tidak berlebihan jika ia disebut mewarisi seluruh warisan pemikiran Islam dan Barat, klasik dan modern dengan mengintegrasikannya secara kreatif untuk membangun tata kehidupan yang dinamis.

Spirit dinamisme itu juga ditampilkan Iqbal dalam perwujudan pengetahuan menjadi tindakan. Di sini tampak Iqbal juga mengitegrasikan pengetahuan dan tindakan, memadukan idealisme dan realisme. Dalam ajaran Islam, pengetahuan adalah dasar tindakan dan tujuan pengetahuan adalah penerapan. Karena itu Iqbal selalu menegaskan bahwa Islam sejatinya adalah agama tindakan. Tindakan yang akan membuat perubahan menuju kemajuan. Karena itu pula Iqbal mengkritik Plato yang terjebak dalam konsep-konsep abstrak tanpa ada perwujudan dalam tindakan. ${ }^{56}$ Tapi tindakan yang dimaksud adalah tindakan positif yang kreatif dan bermanfaat untuk menciptakan perubahan ke arah yang lebih baik. Inilah yang disebut 'amal, yaitu tindakan yang bermuatan ontologis religius dengan penekanan pada moral spiritual Islam, ${ }^{57}$ yang dapat bermanfaat bagi orang lain. Tindakan ini yang disebut Iqbal sebagai tindakan yang mengatasi kematian. ${ }^{58}$ Karena ia tetap berguna setelah kematian orangnya. Dengan ini pula Iqbal merombak teologi klasik yang cenderung teosentris dan pasif pada takdir, menjadi teologi antropomorphis yang mendorong manusia untuk aktif dan kreatif dengan memposisikan manusia sebagai mitra (patner) Tuhan dalam penciptaan. 59

\section{Kesimpulan}

Iqbal adalah pemikir genius yang mewarisi seluruh tradisi pemikiran besar zamannya. Pemikirannya dibangun dari semua sumber dengan berbasis Alquran. Ia menegaskan bahwa sumber pengetahuan adalah afak, anfus, dan sejarah. Ketiganya menyediakan bahan-bahan pengetahuan yang sangat kaya yang dapat diakses oleh manusia. Untuk menjelajahinya, manusia memiliki tiga potensi dalam dirinya: indera, akal dan intuisi. Ketiga potensi tersebut merupakan kesatuan yang digunakan untuk menggali pengetahuan dari ketiga sumber yang juga merupakan kesatuan karena semuanya berasal dari satu Wujud Mutlak. Wujud Mutlak merupakan tujuan akhir kesempurnaan pengetahuan sebagai pengetahuan hakiki yang diidentifikasi Iqbal dengan ma'rifat Allah. Pandangan ini merupakan integrasi sumber pengetahuan dan potensi manusia untuk mencapai kesempurnaan pengetahuan.

Bagi Iqbal, manusia harus terus bergerak menuju pengetahuan hakiki dengan sumber dan potensi yang dimiliki. Itu mungkin dilakukan jika energi 'isyq (cinta) dalam khudi (diri/ego) manusia dimanfaatkan secara maksimal. 'Isyq adalah

\footnotetext{
55 Rohmat Saputro, "Filsafat Cinta Muhamad Iqbal," Jurnal Teologia, Volume 25, Nomor 1, JanuariJuni 2014.

56 Annemarie Schimmel, Sayap Jibril, 47 dan 412.

57 Suhermanto Ja'fat, "Epistemologi Tindakan, 95.

58 Muhammad Iqbal, The Reconstruction of Religious, 102-103.

59 Jeroslav Pelikan, The Treasury of Modern Religious Thought (London: Little Brown and Company, 1990), 319.
} 
kekuatan dinamis yang akan mendorong manusia untuk terus menyempurnakan pengetahuannya sehingga sampai pada puncaknya. Dengan ini manusia menjadi khallifah yang sebenarnya. Kajian terhadap alam dan fenomena sosial serta pengetahuan tentang diri adalan jalan penyempurnaan pengetahuan dengan tetap berpedoman asal wujud yang spiritual. Dalam hal ini Iqbal mengintegrasikan tasawuf dengan ilmu pengetahuan. Karena itu, Iqbal mengkritik tasawuf yang jumud dan tak peduli dunia. Karena bagi Iqbal, dunia harus dipelajari dan ditangani sebagai jalan menuju Tuhan. Karena itu, Iqbal mengambil semangat kemajua dari Barat, termasuk dari konsep elan vital Bergson, ajaran Goethe, bahkan dombrakan Nietzsche atas moraliltas Yahudi dan Kristen serta dan sains modern. Tapi di sisi lain Iqbal mengkritik Barat karena materialisme dan pengabaiannya pada realitas metafisik dan dunia mistik. Dalam hal ini ia banyak merujuk pada metafisika Persia yang didalaminya. Dengan ini, Iqbal juga memperlihatkan integrasi filsafat dan mistik, serta integrasi Barat dan Timur dengan tetap bersikap kritis. Selanjutnya Iqbal juga menyatukan pengetahuan dan tindakan, karena baginya, tindakan positif adalah hakikat 'amal, dan Islam adalah agama 'amal. Karena itu ia mengkritik banyak filosofi Yunan yang terjebak dalam konsep-konsep yang tidak bisa menjadi tindakan.

\section{Daftar Pustaka}

al-Attas, Muhammad Naquib. Islam dan Filsasfat Ilmu Pengetahuan, terj. Saiful Muzani (Bandung: Mizan, 1995).

Al-Jabiri, Muhammad 'Abid Takwin al-'Aqlil al-'Arabi (Beirut: Markaz Dirasat alWahdah al-'Arabiyyah, 1984).

Al-Nadwi, Abu al-Hasan Ali al-Husni. Percikan Kegeniusan Dr. Muhammad Iqbal, terj. Suyibno, Hz. M. (Jakarta: Integrita Press, 1985).

Arif, Syamsuddin. "Prinsip-Prinsip Dasar Epistemologi Islam," dalam Adian Husaini et. Al., Filsafat Ilmu Perspektif Barat dan Islam, (Jakarta: Gema Insani Press, 2013).

Audah, Ali. "Muhammad Iqbal: Sebuah Pengantar" dalam Muhammad Iqbal, Membangun Kembali Pikiran Agama Dalam Islam, terj. Ali Audah (Jakarta: Tintamas, 1982).

Azzam, Abdul Wahhab. Filsafat dan Puisi Iqbal, terj. Ahmad Rofi'i Usman, (Bandung: Pusataka, 1985)

Danusiri. Epistemologi Dalam Tasawuf Iqbal, (Yogyakarta: Pustaka Pelajar, 1996).

Dasuki, A. Hafidz dkk. Ensiklopedi Islam, (Jakarta: Ichtiar Baru van Hoeve, 1994) II: 235-237

Golshani, Mehdi. The Holy Qur'an and the Sciences of Nature, (New York: Global Publications, 1998).

Hafeez Malik (ed.). Iqbal: Poet Philosopher of Pakistan, (New York: Columbia University Press, 1971).

Hidayatullah, Syarif. "Epistemologi Pemikiran Muhammad Iqbal," Jurnal Filsafat, Vol. 24, Nomor 1, Februari 2014, 94-117. 
Hussein, Shahid. "Iqbal's Concept of Personal Identity," dalam Mohammed Ma'ruf (ed.), Contributions to Iqbal's Thought, (Lahore: Islamic Book Service, 1977).

Iqbal, Mohammad. Stay Reflection, ed. Javid Iqbal, SH. (Lahore: Ghulam Ali \&Son, 1961).

Iqbal, Muhammad. Javid Nama, terj. Shaikh Mahmud Ahmad (The Pilgrimage of Eternity (Lahore: Institute of Islamic Culture, 1961).

Iqbal, Muhammad. The Reconstruction of Religious Thoughts in Islam, (New Delhi: Kitab Bhavan, 1981).

Iqbal, Muohammad. Asrar-i Khudi, terj. R. A. Nicholson, (Lahore: Mohammad Ashraf Kasmiri Bazar, 1950).

Ja'far, Suhermanto. "Epistemologi Tindakan Muhammad Iqbal," Jurnal Teosofi, Volume 5, Nomor 1, Juni 2015, 80-106.

Kartanegara, Mulyadhi. Menyingkap Tirai Kejahilan: Pengantar Epistemologi Islam, (Bandung: Mizan, 2003).

Keraf, A. Sonny dan Mikhael dua, Ilmu Pengetahuan: Sebuah Tinjauan Filosofis (Yogyakarta: Kanisius, 2010).

Khan, Iqbal. Some Aspects of Iqbal's Thoughts, (Lahore: Islamic Book Service, 1977).

Lubis, Agus Salim. "Epistemologi Ilmu Pengetahuan dan Relevansinya dalam Studi Al-Qur'an," Jurnal Hermeunetik, Vol. 8, No. 1, Juni 2014, 39-56.

Maimun, Ach. "Mahabbah dalam Tasawuf Rabi'ah al-'Adawiyah (Apresiasi atas Rintisan Mistik Sejati dalam Islam)," Jurnal Millah, Vol III, No. 2, Januari 2004.

Maitre, Miss Luce-Claude. Pengantar ke Pemikiran Iqbal, terj. Djohan Effendi (Bandung: Mizan, 1989).

Munawar, Muhammad. Iqbal and Qur'anic Wisdom, (Lahore: Islamic Book Foundation, 1981).

Nasution, Harun. Pembaharuan dalam Islam, Sejarah Pemikiran dan Gerakan, (Jakarta: Bulan Bintang: 1975).

Pelikan, Jeroslav. The Treasury of Modern Religious Thought (London: Little Brown and Company, 1990).

Saiyidain, K. G. Percikan Filsafat Iqbal Mengenai Pendidikan, terj. M. I Sulaiman, Diponegoro, (Bandung, Pustaka, 1981).

Saputro, Rohmat. "Filsafat Cinta Muhamad Iqbal," Jurnal Teologia, Volume 25, Nomor 1, Januari-Juni 2014.

Schimmel, Annemarie. Sayap Jibril: Gagasan Religius Muhammad Iqbal, terj. Shohifullah, (Yogyakarta: Lazuardi, 2003).

Sharif, M. M. A History of Muslim Philosophy, (Wiesbaden: Ottoharrassowits, 1966).

Sheikh, M. Saeed. "Iqbal's Main Religio-Philosophical Doctrines," dalam Saeed Sheikh (ed.), Studies in Iqbal's Thought and Art, (Lahore: Bazm-i Iqbal, 1972).

Titus, Harold H., Smith dan Nolan. Persoalan-Persoalan Filsafat, terj. H.M. Rasjidi (Jakarta: Bulan Bintang, 1984).

Wardi, Moh. Problematika Pendidikan Islam Dan Solusi Alternatifnya (Perspektif Ontologis, Epistemologis dan Aksiologis), Tadrîs Volume 8 Nomor 1 Juni 2013. 